\title{
Mitä on sivistys?
}

\author{
Heikki Mäki-Kulmala
}

1 Sana "sivistys" tuli suomen kieleen nykyisessä merkityksessään 1800-luvun alkupuolella. Mutta se ei ilmaantunut tyhjästä, vaan oli johdos sanasta "siveä" tai "siviä“. Tuolla sanalla tarkoitettiin sukupuolimoraaliltaan pidättyväistä ihmistä, mutta myös paljon muuta: Siveä ihminen oli myös siisti ja siivo sekä myös arka, nöyrä ja hiljainen. Samaan sanaperheeseen kuuluvat myös "sileä“, "sievä“ tai "siro". Ennen kuin ihmisten sivistämisestä tiedettiin vielä mitään, niin saatettiin monin paikoin Suomea sivistää pellavaa. Se tarkoitti kaikkein hienoimpien kuitujen erottamista karkeammista.

Saksassa sivistystä tarkoittava sana on "die Bildung" ja ruotsalaiset tuntevat hyvin sanan "bildning“. Venäjässä ja sen lähisukukielissä vastaava sana on "obrazovanie". Näissä kaikissa sanoissa voimme tunnistaa kuvaa - tai laajemmin hahmoa tai muotoa - tarkoittavan kantasanan das Bild/en bild/obraz.

Englannissa voidaan sivistyksestä puhuttaessa käyttää ensinnäkin sanaa "education" - ja sama sana löytyy hieman eri tavoin äännettynä myös monista romaanisista kielistä. Tässä kantasanana on ehkä jokin jo indoeurooppalaiseen kantakieleen kuulunut sana, josta on sitten polveutunut latinan duco, joka tarkoittaa vetämistä, johtamista, ohjaamista, taluttamista jne. Sen johdannaisia ovat mm. meidänkin kielemme tuntema "konduktööri", - alun perin ranskan "conducteur". Myös italialaisten aikoinaan hyvin tuntema "il duce" tai englantilaisten herttua "duke" ovat lähtöisin samasta juuresta.

Viimeisenä, mutta ei suinkaan vähäpätöisimpänä, voidaan ottaa vielä esiin sanat "sivilisaatio" ja "kulttuuri", jotka tunnetaan varmasti kaikissa eurooppalaisissa kielissä. Niiden kantasanat - latinan "ciuis", "civilis" tai "cultura", "cultus", "colo" - tarkoittivat maanviljelyä, paikal- laan pysyvää asutusta tai ehkä vain säännöllisesti käytettyä metsästyspolkua.

Kaikissa näissä sanoissa ja niihin liittyvissä mielikuvissa on jotain yhteistä. Sivistys tai kulttuuri on niiden mukaan spontaanin, villin ja usein myös raa'an luonnonvoiman kesyttämistä; kaaoksen järjestykseen saattamista, muodon antamista muodottomalle. Sen saivat kokea myös seitsemän veljestä lukkarin koulussa, kun opettajan jäntevä koura tuon tuostakin kiemurteli heidän tukassaan saattaen sen korkeaan pörröön.

Sivistys on myös paikalleen asettumista, kodin tai talon rakentamista tähän usein tuuliseen maailmaan. Se on suojan rakentamista, sillä luonto on kaikessa ihanuudessaan ja viattomuudessaan myös arvaamaton ja julma. Sivistykseen kuuluu myös muistaminen, kerran hankitun tiedon ja kokemuksen säilyttäminen niin, ettei aivan kaikkea tarvitse aina aloittaa aivan alusta.

2 Sivistyksen ikuinen ja ylin päämäärä on se yksinkertainen kodin onni, jonka Jaroslav Seiffert on niin upeasti tavoittanut runoonsa:

Kodinpienentaivaankannen alla
ompehkorin
jahöyhentupsutohvelien
välisessäovarundessa
hänen kohtunsahehkuvakuu
kasvaanopeastitäydeksi.

Päivänlaskussaan hän on ehtinytjo kiuruihin vaikkavarpuset vielänokkivat unikonsiemeniä jääkukkientakana.

Muttaajuruohontuoksuisessapesäkolossa jokujo virittää sydämen jousta, jotta se pysyisiajassa kokopitkän elämän.

Mutta tämä pieni sopukka ei oikein riitä. Kuka- 
pa haluaisi, että täysi kaaos ja hävityksen kauhistus iskisi kasvoillemme heti, kun avaamme kotimme ulko-oven. Siksi meillä on tapana lakaista lattian lisäksi aina silloin tällöin myös ulkoportaat - ja liikkeelle päästyämme me haluamme siivota koko pihan.

Mutta tähänkään emme halua pysähtyä. Ei ole mukavaa, että täysi kaaos odottaisi meitä heti kotiportin takana. Niinpä myös kylän, sitten seutukunnan, sitten koko valtakunnan ja lopulta koko maapallon asiat pitäisi saada jonkinlaiseen järjestykseen. Haaveenamme on maailma, joka olisi kokonaisuudessaan muuttunut kodiksemme. Eikä meille riitä edes yksi tai muutama autuas hetki - me haluamme tehdä onnestamme kestävän.

3 Jos me kaikki, tai lähes kaikki, ihmiset haluamme tällaista sivistynyttä ja kodiksi muuttunutta maailmaa, niin mistä saa alkunsa pahuus. Uuden ajan rationalisteilla ja sittemmin ns. valistusfilosofeilla oli tähän valmis vastaus: pahuus oli peräisin luonnosta, pahuus oli kaaosta, sivistyksen, lain ja järjestyksen puutetta. Luonnontila ymmärrettiin kaikkien sodaksi kaikkia vastaan. Sellaisissa oloissa ihmisen elämä oli Thomas Hobbesin ikimuistettavien sanojen mukaan "yksinäinen, köyhä, likainen, karkea ja lyhyt", alinomaisen pelon saartama.

Mutta tässä ei kuitenkaan ole läheskään koko totuus pahuuden alkuperästä. Monet sellaiset pahuuden ilmentymät, joita me pidämme erityisen vastenmielisinä ja myös erityisen vaarallisina näyttävät olevan kaikkea muuta kuin luonnontuotteita. Ajatelkaamme esimerkiksi poliittisia tai etnisiä puhdistuksia, jotka eivät suinkaan päättyneet Hitlerin, Stalinin ja Maon luomien valtakuntien tai ideologioitten romahdukseen.

Meidän on pakko hätkähtäen huomata, kuinka etniset tai poliittiset puhdistukset ovat osa suurta siivous- tai sivistysprojektiamme, yritystämme luutia maailmasta kaikki lika ja pahuus pois, tehdä siitä turvallinen koti. On hyvä muistella natsien tai stalinistien mielikuvia siitä, millaiseksi he halusivat maailman luoda. Silmiemme eteen nousevat Aleksandr Deinekan maalaukset, niiden vihannoivat niityt, kirkkaina hoh- tavat taivaat sekä terveet, kauniit, iloiset ja puhtaat ihmiset urheilemassa tai tekemässä työtä. Maailma oli tullut niissä todellakin ihmisten kodiksi - ja ihmiskunta oli yhdentynyt suureksi perheeksi, jossa jokainen toimi kaikkien ja kaikki yhden puolesta.

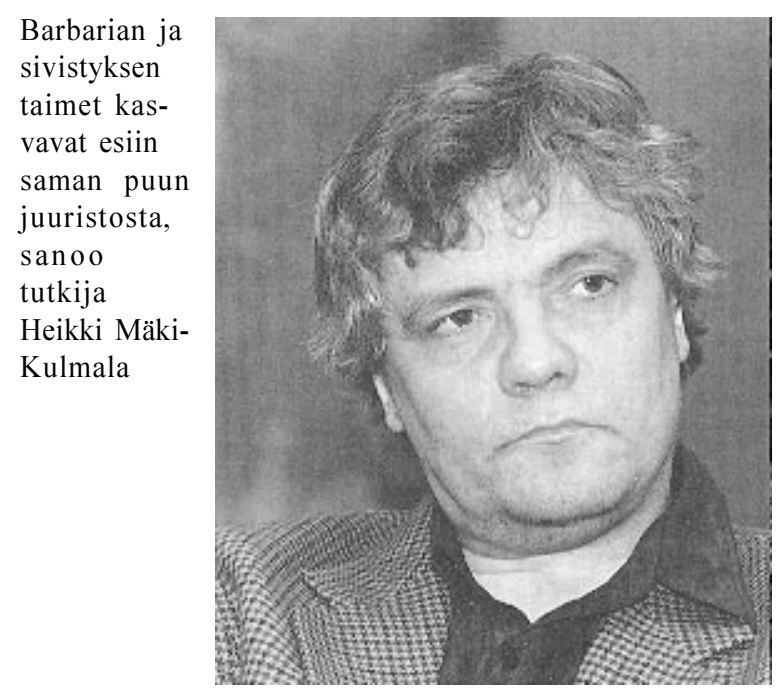

D elottavinta Hitlerin tai Stalinin visioissa ei siis ole niiden outous, vaan tuttuus, että he sittenkin ovat pikemmin "meikäläisiä“" kuin "niitä“. Tässä tulee mieleeni taannoinen kohudokumentti johtavien suomalaislääkäreitten natsiyhteyksistä. Sana "natsilääkäri" tuo aina mieleemme jonkun Josef Mengelen kaltaisen ihmispedon, hänen iljettävät kokeensa ja pakkomielteensä sinisiin silmiin. Mutta jospa tämä onkin vain yritys väistää ja paeta jotain vielä pelottavampaa totuutta: sitä, että paljon suurempi osa natsitohtoreista oli Arvo Ylpön kaltaisia päteviä lääkäreitä, jotka halusivat vain jokaisen syntyvän lapsen olevan elinvoimainen ja terve. "Natsilääkäreitten" enemmistö ei siis ole "niitä" vaan "meikäläisiä“ - eikä heidän sielunelämänsä välttämättä ole valovuosien päässä omastamme.

Samanlaisiin pohdintoihin antaa meille aiheen myös muutaman vuosikymmenen takainen taistolaisuus. Eivät tuonkaan liikkeen jäsenet olleet mitään vallanhaluisia psykopaatteja, terrorin ja väkivallan ihailijoita. He olivat tavallisesti hyvin idealistisia nuoria ihmisiä, jotka halusivat päästää tämän maailman kaikesta pahasta: sodasta, nälästä, saasteista ja kaikesta muustakin kurjuu- 
desta. Juuri tämä puoli asiassa onkin kaikkein pelottavinta.

4 Näyttää siis siltä, että barbarian taimet kasvavat esiin sivistyksen puun juuristosta. Tai että huomattava osa maailman pahuutta aiheutuu yrityksistämme torjua pahuus tai suojautua siltä. Erityisen kouriintuntuva esimerkki tästä on tai oli armeijoitten välinen kilpavarustelu, jonka motiivina on kaikkien rintamalinjojen kaikilla puolilla aina ollut oman turvallisuuden varmistaminen. Tämähän oli keskeinen teesi ehkä kaikkein syvällisimmin natsismin olemusta luodanneessa teoksessa - Max Horkheimerin ja Theodor Adornon Valistuksen dialektiikassa.

Tämä oivallus on samalla ikivanha, ja se vilahtaa esiin mitä moninaisimmissa yhteyksissä. Kuningas Oidipuksen karu kohtalo toteutui juuri siksi, että hänen vanhempansa yrittivät tehdä tyhjäksi sen synkän ennustuksen, jonka oraakkeli oli nuoresta prinssistä lausunut. Shakespearen Macbethin verinen tragedia toteutuu rautaisella vääjäämättömyydellä juuri siksi, että hän yritti voittaa sen.

Samaan tragediaan viittaa jo Raamatun huimaavan syvällinen syntiinlankeemuskertomus: käärmehän viekoitteli Aatamin ja Eevan lupaamalla heille jumalaisen kyvyn nähdä hyvä ja paha ja erottaa ne toisistaan. Tiedon puusta syötyään he huomasivat olevansa alasti ja pukivat ylleen vyöverhot. Tästä juuri alkaa se sivistyksen, suojautumisen ja siistiytymisen historia.

Amerikkalaisen teologin ja kulttuurifilosofin Reinhold Niebuhrin mukaan meidän ajallemme on tyypillistä omahyväinen optimismi. Tämä optimismi ei ole ainoastaan latteaa vaan myös vaarallista siksi, että se ei kykene näkemään niitä pimeitä ja barbaarisia piirteitä, joita hyvääkin tarkoittaviin toimiin vääjäämättä liittyy.

Kun sanoin, että natsilääkärit ovatkin ehkä olleet paljon enemmän Arvo Ylpön kuin Josef Mengelen kaltaisia, niin tällä en suinkaan halua tehdä heidän tekojaan hyväksyttäviksi. Päinvastoin. Meidän on hätkähdettävä huomaamaan, että barbaria on usein paljon lähempänä kuin haluamme uskoa.

Muistan hyvin pienen keskusteluni erään vegaaninuoren kanssa. Hän sanoi nimittäin voivansa vallan mainiosti syödä lihaa - mutta vain siinä tapauksessa, että hän olisi eläimen kasvattanut, siihen ehkä kiintynyt ja lopulta omin käsin teurastanut. Hänellä ei siis ollut mitään lihaa syöviä paimentolais- tai metsästäjäheimoja tai kulttuureja vastaus. Hän ei halunnut erottaa valoa pimeästä, hyvää ateriaa eläimen surmaamisesta. Hänestä ja Reinhold Niebuhrista olisi voinut tulla hyvätkin ystävät. Tämän nuoren ihmisen vegaanisuus oli kapinaa meidän omahyväisyyttämme vastaan.

Luulen myös, että jotain samaa löytyy seuraavasta Eeva-Liisa Mannerin runosta:

Kolme asiaatarvitaan esteettiseenelämykseen: kirkkaus, harmonia, kauneus (Tuomas sanoi),

jasärkyminen, minälisään silläkauneus sinänsäei ole enääkaunis,

\section{eikäole koskaanollut. Metsästäjät sen tietävät, nuojotkarakastavat}

\section{hvvikseen ampumaansaotusta: sitähetkeä jossanäkevätsilmissämurtuvan elämän.}

Voimme nyt tarkastella runoa ja kuvitella, että Eeva-Liisa Manner olisikin puhunut esteettisen elämyksen sijasta sivistyksestä ja sivistyneisyydestä. Varmasti sivistyskin on pyrkimystä kirkkauteen, harmoniaan ja kauneuteen - sellaisen kodin me haluamme.

Mutta "kauneus sinänsä ei ole enää kaunis". Puhtaassa kauneudessa, iankaikkisessa harmoniassa ja kirkkaudessa on jotain jäätävän kylmää ja armotonta. Tällaisen kauneuden tavoittelussa puhdistaminen muuttuu julmuudeksi. Tällainen sivistys ei ole enää sivistystä.

Siksi harmonian, kirkkauden ja kauneuden oheen on liitettävä myös ajatus särkymisestä ja myös nöyrä tietoisuus siitä, että niin barbaria kuin sivistyskin ovat yhden ja saman puun hedelmiä. Tai Walter Benjaminin sanoin: "Jokainen sivistyksen muistomerkki on myös barbarian monumentti".

Heikki Mäki-Kulmalan näkökulma Mitä on sivistys? kuului samannimiseen seminaariin, jonka Kansanvalistusseura järjesti 125-vuotisen toimintansa johdosta Helsingissä Tuomiokirkon kryptassa 3. helmikuuta. 